\title{
KOMPOSISI JENIS DAN STRUKTUR VEGETASI HUTAN DATARAN RENDAH DI KOMPLEKS GUNUNG BULUSARAUNG SULAWESI SELATAN
}

\author{
Species Composition And Structure Vegetation Of Low Land Forest
}

In The Complex Of Bulusaraung Mountain South Sulawesi

\author{
Asrianny ${ }^{1}$, Catarina Balgis Paweka ${ }^{2}$, Amran Achmad ${ }^{1 凶}$, Ngakan Putu Oka ${ }^{1}$, Nida' Sari Achmad ${ }^{3}$ \\ 1Staf Pengajar, Fakultas Kehutanan, Universitas Hasanuddin, Makassar \\ 2Mahasiswa Laboratorium Konservasi Sumberdaya Hutan dan Ekowisata, Universitas Hasanuddin, Makassar. \\ ${ }^{3}$ Eco-Conservation Konsultan, Perdos Unhas Tamanalanrea Blok GB.45, Makassar \\ ${ }^{\otimes}$ corresponding author: amhutan@yahoo.com
}

\begin{abstract}
The Bulusaraung Mountain is a lowland forest and is one of the main ecosystems owned by Bantimurung Bulusaraung National Park. Therefore, this study aims to determine the species composition and vegetation structure of lowland forests in the complex of Bulusaraung Mountain. The research was conducted from April to May 2018. Data collection was carried out using a $20 \mathrm{~m} \times 20 \mathrm{~m}$ plot placed on the Balleanging, Tokaddaro and Tompobulu track lines based on altitude $(550 \mathrm{~m}$ asl, $650 \mathrm{~m}$ asl, and $750 \mathrm{~m}$ asl). The result of this study show that there are 44 species were found on tree class, 65 species on pole class, 40 species on sapling class and 25 species on seedling class. The species composition in the study area was dominated Palaquium obovatum, Persea rimosa, Arthrophyllum diversifolium, Cryptocarya laevigata, and Engelhardia serrata, while Psychotria leptothyrsa, Antidesma bunius, Maesa ramentacea, Ficus sandpaper, Baccaurea javanica, Symplocos maliliency, Callicarpa pentandra, and Saurauia tristylais a type of tree that differentiates at each altitude. The structure of the forest canopy layer at an altitude of $550 \mathrm{~m}$ above sea level consists of three canopy layers, while at an altitude of 650 and $750 \mathrm{~m}$ above sea level consisting only of two canopy layers. The cover of forest canopy in all sampling locationswas reached $75-90 \%$.
\end{abstract}

Keywords: Lowland forest, Bulusaraungmountain, species composition, vegetation structure

\section{A. PENDAHULUAN}

Hutan adalah suatu kesatuan ekosistem berupa hamparan lahan berisi sumberdaya alam hayati yang didominasi oleh pepohonan dalam komunitas alam lingkungannya yang tidak dapat dipisahkan antara satu dengan yang lainnya (UU RI Nomor 18 Tahun 2013). Hutan di Indonesia mempunyai tiga tipe ekosistem alami, yaitu hutan monson, hutan pegunungan, dan hutan dataran rendah (Pamulardi, 1999). Hutan dataran rendah terletak pada ketinggian 0 - 1000 meter dari permukaan laut dan merupakan bagian terbesar hutan yang mencakup kawasan yang paling luas di Indonesia. Hutan dataran rendah ditandai dengan adanya tumbuhan pemanjat pohon yang banyak dan lebat, pohon-pohon berbanir besar dan banyak pohon-pohon dengan batang yang tinggi bulat mempunyai kulit yang halus (Anwar et al., 1992). Di hutan dataran rendah banyak terdapat spesies pohon anggota famili Dipterocarpaceae, selain itu terdapat famili Lauraceae, Myrtaceae, Miristicaceae, dan Ebenaceae (Soerianegara \& Indrawan, 2016).

Menurut Soerianegara dan Indrawan (2016), hutan dataran rendah dapat dikelompokkan kedalam dua kategori, yakni hutan dataran rendah Dipterocarpaceae yang didominasi oleh genus Shorea, Dipterocarpus, Dryobalonops, Cotylelobium dan Hopea. Sedangkan hutan dataran rendah Non-Dipterocarpaceae yang didominasi oleh genus Anisoptera, Hopea, Shorea, dan Vatica (Mongabay, 2012). Hutan dataran rendah Dipterocarpaceae menyebar di wilayah Indonesia bagian barat khususnya di pulau Kalimantan dan Sumatera, dan Malaysia, Brunei, Filipina (Ashton, 1982). Sementara hutan dataran rendah Non-Dipterocarpaceae di temukan di belahan Indonesia bagian timur Sulawesi, Maluku, BaliLombok, dan Papua-Nugini (Purwaningsih, 2004).

Hutan dataran rendah adalah salah satu jenis tegakan yang perlu diteliti struktur dan komposisinya dikarenakan areal ekosistem dataran rendah memiliki kekayaan keanekaragaman hayati dan tingkat endemisme yang tinggi. Namun demikian, pada umumnya hutan ini telah banyak mengalami degradasi karena dekatnya pemukiman masyarakat sehingga dapat rentan kehilangan sumberdaya genetika.

Salah satu hutan dataran rendah NonDipterocarpaceae yang ditemukan di Pulau Sulawesi adalah hutan dataran rendah di Kompleks Gunung 
Bulusaraung. Gunung Bulusaraung merupakan kawasan Taman Nasional Bantimurung Bulusaraung, dimana hutan dataran rendah di lokasi ini adalah salah satu ekosistem utama yang dimiliki oleh TN BABUL.Sampai saat ini belum pernah dilakukan penelitian yang mendalam tentang potensi keanekaragaman hayati di hutan dataran rendah tersebut, sehingga dengan demikian potensi hutan yang ada di areal tersebut sangat perlu dikaji.Penelitian ini bertujuan untuk mengetahui komposisi jenis dan strukur vegetasi hutan di Kompleks Gunung Bulusaraung untuk bisa dijadikan pertimbangan dalam perencanaan dan pengembangan TN BABUL.

\section{B. METODE PENELITIAN}

\section{Metode Pengumpulan Data}

Penempatan plot diletakkan pada tiga jalur yakni Jalur Balleanging, Jalur Kattokaddaro dan Jalur Tompobulu, dimana setiap jalur mengarah ke puncak Gunung Bulusaraung. Dalam setiap jalur diletakkan sebanyak 3 plot secara sistematik sampling berdasarkan perbedaan ketinggian setiap $100 \mathrm{~m}$ dpl, yang dimulai pada ketinggian $550 \mathrm{~m}$ dpl pada lokasi yang bervegetasi. Untuk lebih jelasnya ketiga jalur tempat peletakan plot dapat dilihat pada Gambar 1.
Ukuran plot contoh yang digunakan $20 \mathrm{~m} \times 20 \mathrm{~m}$. Setiap plot dibagi menjadi 4 sub plot guna memudahkan pengambilan data. Luas pengukuran tingkat pohon dan tiang sebesar $20 \mathrm{~m} \times 20 \mathrm{~m}$, tingkat pancang sebesar $20 \mathrm{~m}$ $x 10 \mathrm{~m}$ sisi kanan plot contoh dan tingkat semai sebesar 2 $\mathrm{m} \times 2 \mathrm{~m}$ seperti diperlihatkan pada Gambar 2 .

Setiap pohon yang berdiameter $>5 \mathrm{~cm}$ dicatat nama jenisnya dan diukur diameternya. Adapun pohon yang berdiameter $<5 \mathrm{~cm}$ dicatat nama jenis dan jumlahnya dalam subplot $10 \mathrm{~m} \times 20 \mathrm{~m}$ sisi kanan. Tingkatan semai dicatat nama jenis dan jumlahnya pada subplot $2 \mathrm{~m} \times 2 \mathrm{~m}$.

Pada plot berukuran $20 \mathrm{~m} \times 20 \mathrm{~m}$ juga dilakukan penggambar proyeksi tajuk, sedangkan pada plot berukuran $10 \mathrm{~m} \times 20 \mathrm{~m}$ dilakukan penggambaran diagram profil seperti di perlihatkan pada Gambar 3 dan Gambar 4.

\section{Analisis Data}

Analisis kuantitatif digunakan untuk mendeskripsikan komposisi jenis dan struktur tegakan yang dijumpai. untuk memperoleh data luas bidang dasar, kerapatan, frekuensi, dominansi, indeks nilai penting, indekskeanekaragaman jenis, indeks kekayaan, indeks kemerataan dan indeks kesamaan komunitas.

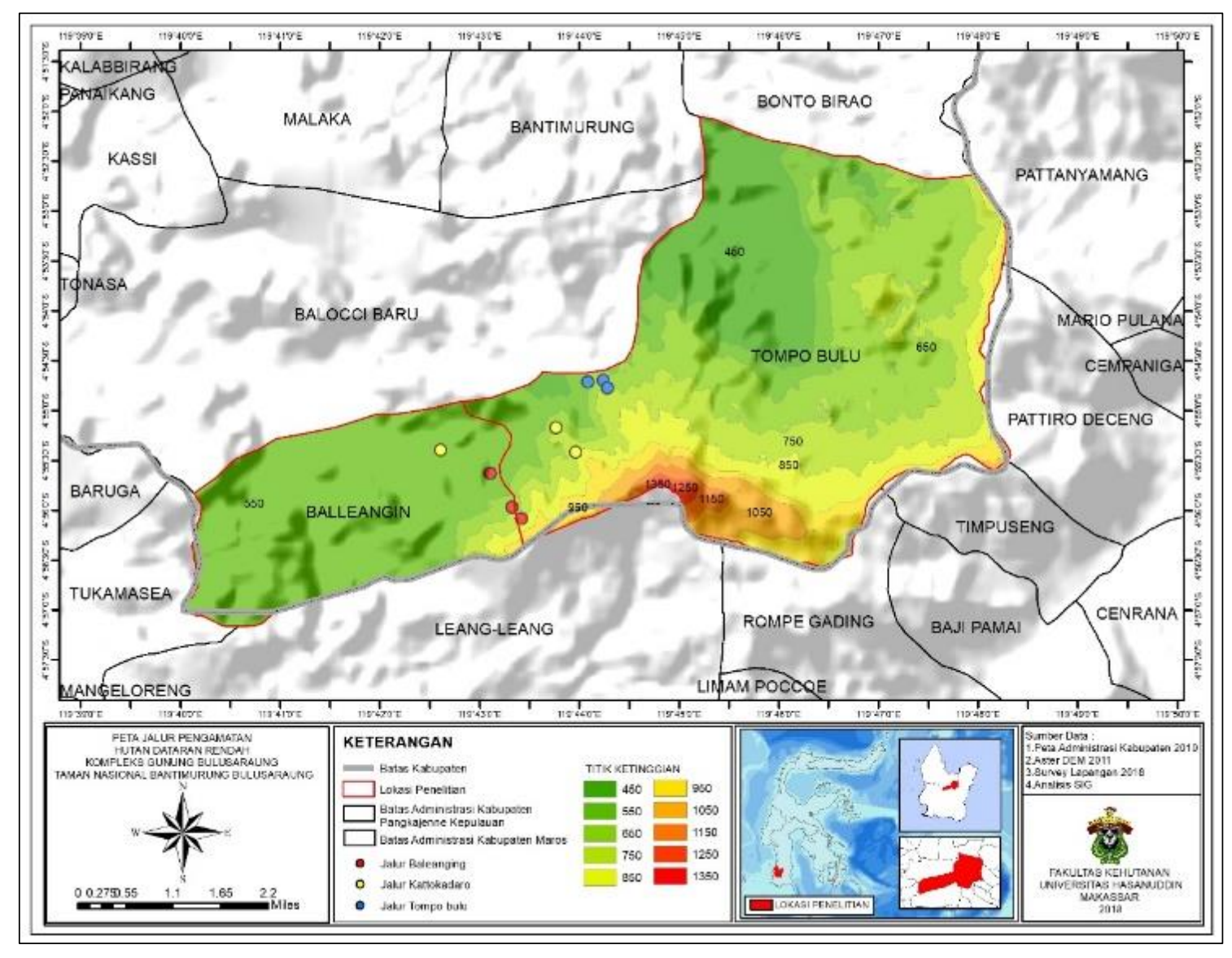

Gambar 1. Peta pengamatan 


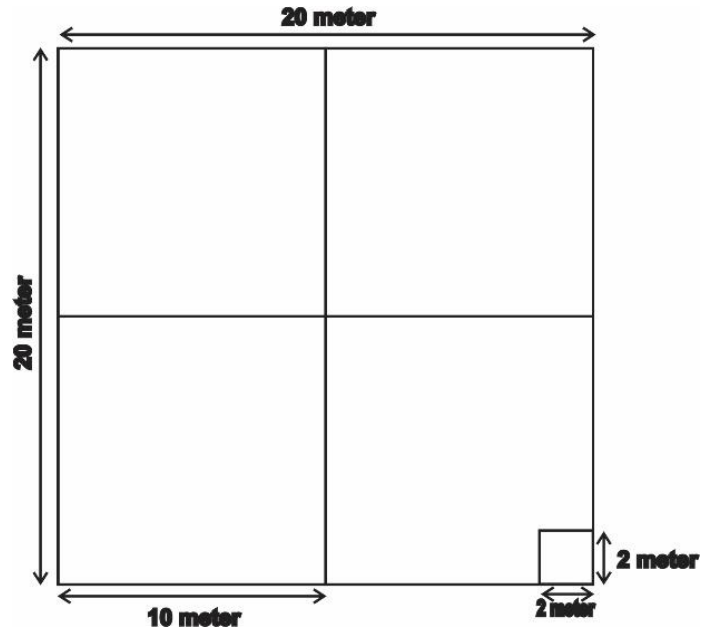

Gambar 2. llustrasi contoh plot

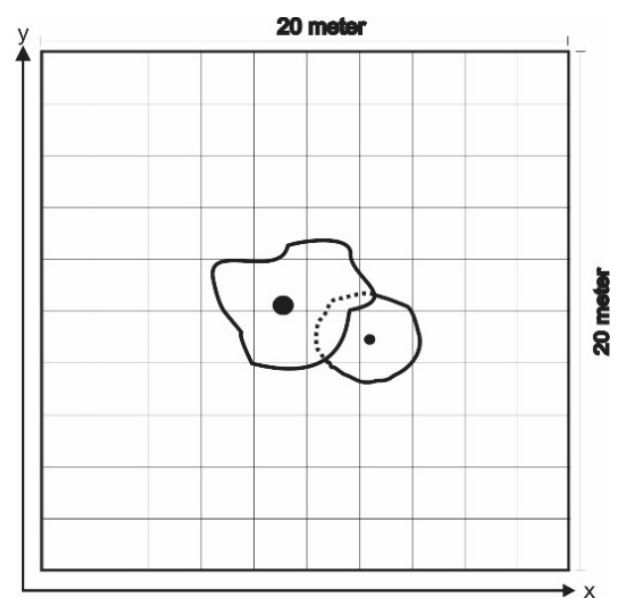

Gambar 3. llustrasi plot proyeksi tajuk

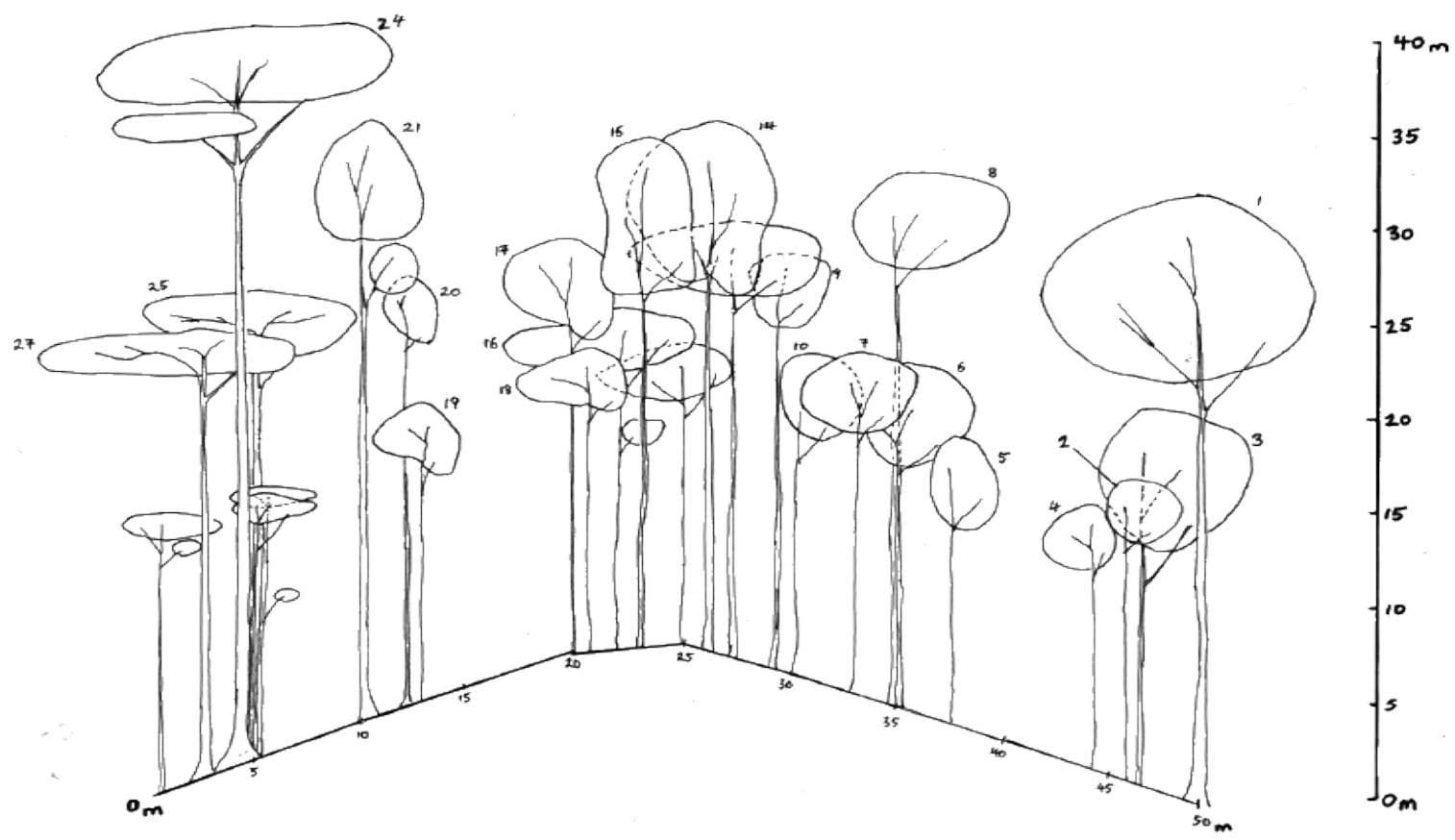

Gambar 4. llustrasi bagan profil pohon. 


\section{HASIL DAN PEMBAHASAN}

\section{Hasil}

\section{Komposisi dan Sebaran Jenis}

Hasil penelitian ini ditemukan sebanyak 44 jenis tingkat pohon, 65 jenis tingkat tiang, 40 jenis tingkat pancang, dan 25 jenis tingkat semai. Delapan puluh dua jenis tumbuhan dari 37 famili telah berhasil diidentifikasi, dan 13 jenis tumbuhan lainnya hanya sampai ditingkatan nama lokal. Sebaran jenis tumbuhan berdasarkan ketinggian tempat dari permukaan laut diperlihatkan pada Tabel 1.

Tabel 1. Distribusi jenis tanaman berdasarkan ketinggian

\begin{tabular}{|c|c|c|c|c|c|c|}
\hline \multirow{2}{*}{ No } & \multirow{2}{*}{ Nama Lokal } & \multirow{2}{*}{ Nama Latin } & \multirow{2}{*}{ Famili } & \multicolumn{3}{|c|}{ Ketinggian (m dpl) } \\
\hline & & & & 550 & 650 & 750 \\
\hline 1 & Bakang bitotoeng & Neolitsea javanica & Lauraceae & $\checkmark$ & $\checkmark$ & $\checkmark$ \\
\hline 2 & Bakang Taipa & Litsea pallida & Lauraceae & $\checkmark$ & $\checkmark$ & $\checkmark$ \\
\hline 3 & Bintahang & Neonauclea excelsa & Rubiaceae & $\checkmark$ & $\checkmark$ & $\checkmark$ \\
\hline 4 & Bitao & Calophyllum sp. & Calophyllaceae & $\checkmark$ & $\checkmark$ & $\checkmark$ \\
\hline 5 & Bontang-bontang & Sp 8 & & $\checkmark$ & $\checkmark$ & $\checkmark$ \\
\hline 6 & Dao & Dracontomelon dao & Anacardiaceae & $\checkmark$ & $\checkmark$ & $\checkmark$ \\
\hline 7 & Garassi & Beilschmiedia gemmiflora & Lauraceae & $\checkmark$ & $\checkmark$ & $\checkmark$ \\
\hline 8 & Jambu ri jene & Syzygium rostratum & Myrtaceae & $\checkmark$ & $\checkmark$ & $\checkmark$ \\
\hline 9 & Kasunu & Lithocarpus celebicus & Fagaceae & $\checkmark$ & $\checkmark$ & $\checkmark$ \\
\hline 10 & Lento-lento & Arthrophyllum diversifolium & Araliaceae & $\checkmark$ & $\checkmark$ & $\checkmark$ \\
\hline 11 & Locong-locong & Euphorianthus euneurus & Annonaceae & $\checkmark$ & $\checkmark$ & $\checkmark$ \\
\hline 12 & Mahai botto & Mitrephora celebica & Annonaceae & $\checkmark$ & $\checkmark$ & $\checkmark$ \\
\hline 13 & Mara-mara sikapa & Melicope triphylla & Rutaceae & $\checkmark$ & $\checkmark$ & $\checkmark$ \\
\hline 14 & Pajung-pajung & Elaeocarpus sp. & Elaeocarpaceae & $\checkmark$ & $\checkmark$ & $\checkmark$ \\
\hline 15 & Pangi-pangi & Cryptocarya ferrea & Lauraceae & $\checkmark$ & $\checkmark$ & $\checkmark$ \\
\hline 16 & Pattung-pattung & Garcinia treubii & Clusiaceae & $\checkmark$ & $\checkmark$ & $\checkmark$ \\
\hline 17 & Sipi-sipi & Psydrax dicoccos & Rubiaceae & $\checkmark$ & $\checkmark$ & $\checkmark$ \\
\hline 18 & Susuang & Phaleria octandra & Thymelaeaceae & $\checkmark$ & $\checkmark$ & $\checkmark$ \\
\hline 19 & Tampallang kacci & Persea rimosa & Lauraceae & $\checkmark$ & $\checkmark$ & $\checkmark$ \\
\hline 20 & Tappu & Cryptocarya laevigata & Lauraceae & $\checkmark$ & $\checkmark$ & $\checkmark$ \\
\hline 21 & Tera-terasa & Dyctyoneura acuminate & Sapindaceae & $\checkmark$ & $\checkmark$ & $\checkmark$ \\
\hline 22 & Tera-terasa laki & Guioa diplopetala & Sapindaceae & $\checkmark$ & $\checkmark$ & $\checkmark$ \\
\hline 23 & Arita & Alstonia scholaris & Apocynaceae & $\checkmark$ & $\checkmark$ & - \\
\hline 24 & Bisuhu & Magnolia lilifera & Magnoliaceae & $\checkmark$ & $\checkmark$ & - \\
\hline 25 & Bosi-bosi & Dillenia serrata & Dilleniaceae & $\checkmark$ & $\checkmark$ & - \\
\hline 26 & Damar-damar putih & Canarium asperum & Burseraceae & $\checkmark$ & $\checkmark$ & - \\
\hline 27 & Malapao & Buchanania arborescens & Anacardiaceae & $\checkmark$ & $\checkmark$ & - \\
\hline 28 & Orisi & Koordersiodendron pinnatum & Anacardiaceae & $\checkmark$ & $\checkmark$ & - \\
\hline 29 & Rao dare & Timonius minahasae & Rubiaceae & $\checkmark$ & $\checkmark$ & - \\
\hline 30 & Tayinna lolo & Garcinia lateriflora & Clusiaceae & $\checkmark$ & $\checkmark$ & - \\
\hline 31 & Mana-mana & Alchornea rugose & Euphorbiaceae & $\checkmark$ & $\checkmark$ & - \\
\hline 32 & Bakang Lamma & Litsea ochracea & Lauraceae & - & $\checkmark$ & $\checkmark$ \\
\hline 33 & Binappu & Horsfieldia lancifolia & Myristicaceae & - & $\checkmark$ & $\checkmark$ \\
\hline 34 & Cabarentu & Beilschmiedia gemmiflora & Lauraceae & - & $\checkmark$ & $\checkmark$ \\
\hline 35 & Katangka & Rhadermachera pinnata & Bignoniaceae & - & $\checkmark$ & $\checkmark$ \\
\hline 36 & Lemo-lemo & Rothmannia merrilli & Rubiaceae & - & $\checkmark$ & $\checkmark$ \\
\hline 37 & Malaka & Phyllanthus emblica & Phyllanthaceae & - & $\checkmark$ & $\checkmark$ \\
\hline 38 & Taipa bahang & Mangifera laurina & Anacardiaceae & - & $\checkmark$ & $\checkmark$ \\
\hline 39 & A'ba-a'ba & Steganthera elliptica & Monimiaceae & $\checkmark$ & - & $\checkmark$ \\
\hline 40 & Banyoro & Pterospermum celebicum & Malvaceae & $\checkmark$ & - & $\checkmark$ \\
\hline ; 41 & Galingkang & Nothaphoebe patentinervis & Lauraceae & $\checkmark$ & - & $\checkmark$ \\
\hline
\end{tabular}


Tabel 1. Distribusi jenis tanaman berdasarkan ketinggian (lanjutan)

\begin{tabular}{|c|c|c|c|c|c|c|}
\hline \multirow{2}{*}{ No } & \multirow{2}{*}{ Nama Lokal } & \multirow{2}{*}{ Nama Latin } & \multirow{2}{*}{ Famili } & \multicolumn{3}{|c|}{ Ketinggian (m dpl) } \\
\hline & & & & 550 & 650 & 750 \\
\hline 42 & Garu & Aglaia elliptica & Meliaceae & $\checkmark$ & - & $\checkmark$ \\
\hline 43 & Jampu-jampu & Sp 4 & & $\checkmark$ & - & $\checkmark$ \\
\hline 44 & Kenanga & Canangium odoratum & Annonaceae & $\checkmark$ & - & $\checkmark$ \\
\hline 45 & Mali-mali & Leea indica & Vitaceae & $\checkmark$ & - & $\checkmark$ \\
\hline 46 & Nyato & Palaquium obovatum & Sapotaceae & $\checkmark$ & - & $\checkmark$ \\
\hline 47 & Puca Lakkang & Heritiera sylvatica & Malvaceae & $\checkmark$ & - & $\checkmark$ \\
\hline 48 & Angkame (liana) & Anodendron paniculatum & Apocynaceae & $\checkmark$ & - & - \\
\hline 49 & Bera-berasa & Maesa ramentacea & Primulaceae & $\checkmark$ & - & - \\
\hline 50 & Bicoro & Melastoma malabathricum & Melastomataceae & $\checkmark$ & - & - \\
\hline 51 & Bilalang & Sp 5 & & $\checkmark$ & - & - \\
\hline 52 & Bune & Antidesma bunius & Phyllanthaceae & $\checkmark$ & - & - \\
\hline 53 & Katondeng palliasa & Sp 1 & & $\checkmark$ & - & - \\
\hline 54 & Kayu kerambu & Cipadessa baccifera & Meliaceae & $\checkmark$ & - & - \\
\hline 55 & Kelong & Antidesma tomentosum & Phyllanthaceae & $\checkmark$ & - & - \\
\hline 56 & Kemiri & Aleurites moluccana & Euphorbiaceae & $\checkmark$ & - & - \\
\hline 57 & Kodong-kodong & Sp 3 & & $\checkmark$ & - & - \\
\hline 58 & Lamporo-lamporo bayi & Psychotria leptothyrsa & Rubiaceae & $\checkmark$ & - & - \\
\hline 59 & Mahai & Xylopia peekelii & Annonaceae & $\checkmark$ & - & - \\
\hline 60 & Mani-mani & Lasianthus stercorarius & Rubiaceae & $\checkmark$ & - & - \\
\hline 61 & Bakang Katala & Litsea mappacea & Lauraceae & - & $\checkmark$ & - \\
\hline 62 & Impallasa & Ficus amplas & Moraceae & - & $\checkmark$ & - \\
\hline 63 & Inranlo & Sp 7 & & - & $\checkmark$ & - \\
\hline 64 & Lambiri & Sp 9 & & - & $\checkmark$ & - \\
\hline 65 & Lamolo (liana) & Tetrastigma trifoliatum & Vitaceae & - & $\checkmark$ & - \\
\hline 66 & Lica-lica romang & Psychotria celebica & Rubiaceae & - & $\checkmark$ & - \\
\hline 67 & Maranne & Sp 6 & & - & $\checkmark$ & - \\
\hline 68 & Ropisi & Baccaurea javanica & Phyllanthaceae & - & $\checkmark$ & - \\
\hline 69 & Sattulu' & Sandoricum coetcape & Meliaceae & - & $\checkmark$ & - \\
\hline 70 & Tumea & Pleiogynium Timorese & Anacardiaceae & - & $\checkmark$ & - \\
\hline 71 & Bilalang bassi & Sp 10 & & - & - & $\checkmark$ \\
\hline 72 & Bintahang laki & Ixora imitans & Rubiaceae & - & - & $\checkmark$ \\
\hline 73 & Dadi-dadi & Symplocos maliliensi & Symplocaceae & - & - & $\checkmark$ \\
\hline 74 & Gammi & Pterocymbium tinctorium & Malvaceae & - & - & $\checkmark$ \\
\hline 75 & Ganjeng-ganjeng & Piper miniatum & Piperaceae & - & - & $\checkmark$ \\
\hline 76 & Jambu garassi & Sp 12 & & - & - & $\checkmark$ \\
\hline 77 & Kajuara & Ficus benjamina & Moraceae & - & - & $\checkmark$ \\
\hline 78 & Kali mokere & Tarennoidea wallichii & Rubiaceae & - & - & $\checkmark$ \\
\hline 79 & Kalumpenga & Oreocnide rubescens & Urticaceae & - & - & $\checkmark$ \\
\hline 80 & Katabo & Mallotus repandus & Phyllanthaceae & - & - & $\checkmark$ \\
\hline 81 & Kayu bunga & Engelhardia serrata & Juglandaceae & - & - & $\checkmark$ \\
\hline 82 & Kayu pala & Sp 11 & & - & - & $\checkmark$ \\
\hline 83 & Kayu saleang & Prunus arborea & Rosaceae & - & - & $\checkmark$ \\
\hline 84 & Keru-keru & Ficus geocharpa & Moraceae & - & - & $\checkmark$ \\
\hline 85 & Lalatang manu & Sp 2 & Urticaceae & - & - & $\checkmark$ \\
\hline 86 & Lambu-lambu & Mallotus mollissimus & Euphorbiaceae & - & - & $\checkmark$ \\
\hline 87 & Lasisi parang & Glochidion sp. & Phyllanthaceae & - & - & $\checkmark$ \\
\hline 88 & Lutu & Sp 13 & & - & - & $\checkmark$ \\
\hline 89 & Mata allo & Callicarpa pentandra & Lamiaceae & - & - & $\checkmark$ \\
\hline 90 & Ninning & Saurauia tristyla & Actinidiaceae & - & - & $\checkmark$ \\
\hline 91 & Pala-pala & Myristica impressa & Myristicaceae & - & - & $\checkmark$ \\
\hline 92 & Pamerakkang & Knema globularia & Myristicaceae & - & - & $\checkmark$ \\
\hline
\end{tabular}


Tabel 1. Distribusi jenis tanaman berdasarkan ketinggian (lanjutan)

\begin{tabular}{llllccc}
\hline \multirow{2}{*}{ No } & \multirow{2}{*}{ Nama Lokal } & \multicolumn{2}{c}{ Nama Latin } & \multirow{2}{*}{ Famili } & \multicolumn{3}{c}{ Ketinggian (m dpl) } \\
& & Glochidion lutescens & Phyllanthaceae & - & - & $\mathbf{6 5 0}$ \\
\hline 93 & Paradeang & Planchonia valida & Lecythidaceae & - & - & $\checkmark$ \\
94 & Pucak sasa & Acer laurinum & Sapindaceae & - & - & $\checkmark$ \\
95 & Putih sihali & Total & & 186 & $\mathbf{2 3 8}$ & $\mathbf{2 5 3}$ \\
\hline & & & &
\end{tabular}

Tabel 1 memperlihatkan bahwa sebaran tumbuhan pada ketiga ketinggian dapat dikelompokkan kedalam 7 kelompok berdasarkan kehadiran tiap jenis.. Kelompok pertama yang ditemui pada ketinggian $550 \mathrm{~m} \mathrm{dpl}-750 \mathrm{~m}$ $\mathrm{dpl}$, terdiri dari 22 jenis. Beberapa diantaranya adalah Neolitsea javanica, Arthrophyllum diversifolium, Persea rimosa, Lithocarpus celebicus, dan Psydrax dicoccos. Kelompok kedua ditemui hanya pada ketinggian $550 \mathrm{~m} \mathrm{dpl}$ dan $650 \mathrm{~m}$ dpl. Kelompok ini terdiri dari 9 jenis, beberapa diantaranya yaitu Alstonia scholaris, Dillenia serrata, Buchanania arborescens, dan Garcinia lateriflora. Kelompok ketiga ditemui pada ketinggian $650 \mathrm{~m}$ dpl dan $750 \mathrm{~m} \mathrm{dpl}$ yang ditemui ialah Horsfieldia lancifolia, Rothmannia merrilli, Phyllanthus emblica, dan Litsea ochracea. Kelompok keempat ditemui pada ketinggian 550 $\mathrm{m}$ dpl dan $750 \mathrm{~m}$ dpl yang terdiri dari 9 jenis. Beberapa jenis diantaranya yang ditemukan ialah Steganthera elliptica, Pterospermum celebicum, Nothaphoebe patentinervis, dan Aglaia elliptica. Kelompok kelima ditemukan hanya pada satu petak saja. Pada ketinggian $550 \mathrm{~m}$ dpl ditemukan 13 jenis, adapun beberapa diantaranya Psychotria leptothyrsa, Antidesma bunius, Maesa ramentacea, dan Anodendron paniculatum. Kelompok keenam, Ficus amplas, Litsea mappacea, Baccaurea javanica, dan Tetrastigma trifoliatum adalah beberapa diantara jenis yang ditemukan pada ketinggian $650 \mathrm{~m}$ dpl. Kelompok terakhir pada ketinggian $750 \mathrm{~m}$ dpl, diantaranya Symplocos maliliensi, Callicarpa pentandra, Pterocymbium tinctorium, dan Saurauia tristyla adalah beberapa jenis lain yang ditemukan.

\section{Indeks Nilai Penting}

Indeks nilai penting suatu jenis pada setiap tingkat pertumbuhan mengalami perubahan seiring dengan pertambahan ketinggian. Hasil perhitungan INP pada tingkatan pohon memperlihatkan bahwah ketinggian 550 mdpl pada tingkat pohon didominasi oleh Palaquium obovatum sebesar $43,83 \%$, pada $650 \mathrm{~m}$ dpl adalah Persea rimosa (40,89\%), dan pada ketinggian $750 \mathrm{~m} \mathrm{dpl}$ Arthrophyllum diversifolium $(47,93 \%)$. Jenis tiang yang mendominasi pada ketinggian $550 \mathrm{~m} \mathrm{dpl}$ adalah Cryptocarya laevigatadengan INP sebesar $57,60 \%$. Pada ketinggian $650 \mathrm{~m} \mathrm{dpl}$ dan $750 \mathrm{~m}$ dpl jenis yang mendominasi adalah Arthrophyllum diversifolium dengan INP berturut-turut sebesar $57,82 \%$ dan $57,08 \%$. Pada tingkatan pancang yang mendominasi pada ketinggian $550 \mathrm{~m}$ dpl dan $650 \mathrm{~m}$ dpl adalah Dyctyoneura acuminatadengan INP berturut-turut sebesar $34,72 \%$ dan
39,04\%, dan pada ketinggian $750 \mathrm{~m} \mathrm{dpl}$, jenis pancangyang mendominasi adalah Cryptocarya ferrea dengan INP sebesar $20,55 \%$. Sedangkan jenis tumbuhan tingkat semai yang mendominasi pada ketinggian $550 \mathrm{~m}$ $\mathrm{dpl}$ adalah Psychotria leptothyrsa (22,98\%), pada ketinggian $650 \mathrm{~m}$ dpl adalah Persea rimosa (30,77\%), dan pada ketinggian $750 \mathrm{~m} \mathrm{dpl}$ adalah Cryptocarya ferrea $(40,67 \%)$.

\section{Indeks Ekologi}

Indeks ekologi terdiri dari Indeks Kekayaan Jenis (R), Indeks Kemerataan Jenis $(\mathrm{E})$, Indeks Keanekaragaman Jenis $\left(H^{\prime}\right)$, dan Indeks Kesamaan Komunitas. Indeks ekologi diperlihatkan pada Tabel 2. Indeks keanekaragaman jenis tertinggi adalah tingkatanIndeks kekayaan jenis tertinggi pada tingkat semai terdapat pada ketinggian $550 \mathrm{~m}$ dpl dengan nilai $\mathrm{R}$ sebesar 2,62, pada tingkat tiang dan pancang terdapat pada ketinggian $750 \mathrm{~m}$ dpl dengan nilai R masing-masing sebesar 3,20 dan 3,69. Sedangkan pada tingkat pohon terdapat pada ketinggian $650 \mathrm{~m}$ dpl dengan nilai $R$ sebesar 3,59. Kemudian indeks kemerataan pada ketiga ketinggian tempat untuk setiap tingkatan pertumbuhan memiliki nilai diatas 0,75 . Hal ini menunjukkan bahwa komunitas pada ketinggian 550 - 750 mdpl termasuk komunitas stabil.

Tabel 2. Indeks Kesamaan Komunitas berdasarkan ketinggian tempat

\begin{tabular}{cccc}
\hline $\begin{array}{c}\text { Ketinggian } \\
\text { Tempat }\end{array}$ & $550 \mathrm{mdpl}$ & $650 \mathrm{mdpl}$ & $750 \mathrm{mdpl}$ \\
\hline $550 \mathrm{~m} \mathrm{dpl}$ & 100 & 62 & 53,6 \\
$650 \mathrm{~m} \mathrm{dpl}$ & - & 100 & 49,1 \\
$750 \mathrm{~m} \mathrm{dpl}$ & - & - & 100 \\
\hline
\end{tabular}

Nilai indeks kesamaan komunitas yang didapatkan berkisar antara 49,1 - 62. Semakin besar nilai indeks kesamaan, maka komposisi jenis diantara dua komunitas yang dibandingkan semakin sama. Nilai indeks kesamaan tertinggi terdapat pada ketinggian $550 \mathrm{~m}$ dpl dengan 650 $\mathrm{m}$ dpl dengan indeks kesamaan sebesar 62. Pada ketinggian $650 \mathrm{~m}$ dpl dengan $750 \mathrm{~m}$ dpl sebesar 49,1, dan pada ketinggian $550 \mathrm{~m}$ dpl dengan $750 \mathrm{~m}$ dpl dengan nilai indeks kesamaan komunitas sebesar 53,6. Berdasarkan kriteria indeks kesamaan jenis, pada ketinggian $550 \mathrm{~m} \mathrm{dpl}$ dengan $650 \mathrm{~m}$ dpl dan ketinggian $550 \mathrm{~m}$ dpl dengan 750 $\mathrm{m}$ dpl merupakan dua komunitas yang dianggap mirip. 
Sedangkan padaketinggian $650 \mathrm{~m}$ dpl dengan $750 \mathrm{~m}$ dpl merupakan dua komunitas yang dianggap berbeda.

\section{Struktur Vegetasi dan Penutupan Tajuk Hutan}

Struktur tegakan vertikal dapat diketahui dari hubungan antara kerapatan pohon dengan kelas tinggi pohon (lapisan tajuk). Dari tiga petak yang diperbandingkan antara ketinggian 550, 650, dan $750 \mathrm{~m}$ $\mathrm{dpl}$, ada perbedaan strata hutan yang ditemukan pada ketinggian $550 \mathrm{~m}$ dpl dan ketinggian 650-750 m dpl. Pada ketinggian $550 \mathrm{~m}$ vegetasi hutan tersusun atas 3 lapisan tajuk, sedangkan pada ketinggian $650 \mathrm{~m}$ dan $750 \mathrm{~m}$ hanya tersusun atas 2 lapisan tajuk.

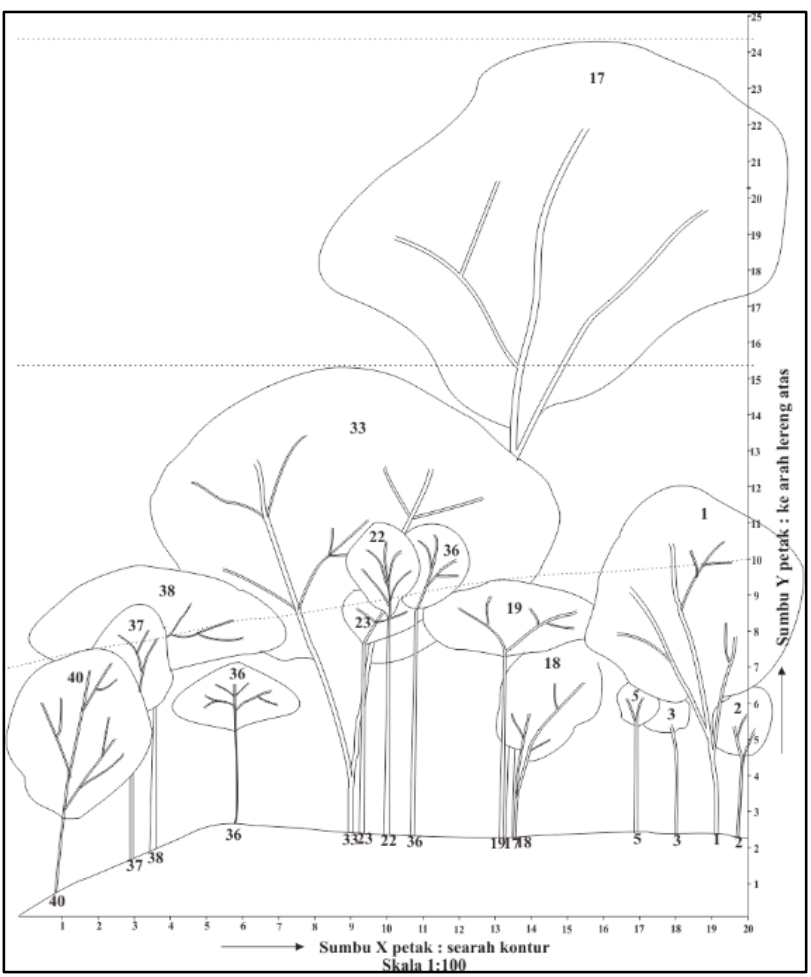

Gambar 5. Diagram profil pohon pada ketinggian $550 \mathrm{~m} \mathrm{dpl}$ (angka menunjukkan nomor pohon)

Pada ketinggian $550 \mathrm{~m} \mathrm{dpl}$, lapisan tajuk paling yang tingginya berada antara $17-25 \mathrm{~m}$, terdiri oleh jenis Cipadessa baccifera. Lapisan kedua yang tinggi pohonnya antara 8-17 m di isi oleh jenis Lithocarpus celebicus, Persea rimosa, Arthrophyllumdiversifolium, Cryptocarya laevigata, Canarium asperum, Melicope triphylla, Nothaphoebe patentinervis, Euphorianthus euneurus, dan Calophyllum sp. Lapisan ketiga yang tinggi pohonnya antara 1-8m, diisi oleh jenis Garcinia treubii, Litsea pallida, Mitrephora celebica, Garcinia treubii, Guioank diplopetala, dan Phaleria octandra. Struktur vegetasi hutan pada ketinggian $550 \mathrm{~m}$ dpl diperlihatkan pada Gambar 5 . Berdasarkan hasil analisis data ditemukan bahwa tutupan tajuk hutan pada ketinggian $550 \mathrm{~m}$ dpl mencapai 80 hingga $90 \%$. Kenampakan penutupan tajuk hutan tersebut, diperlihatkan pada Gambar 6.

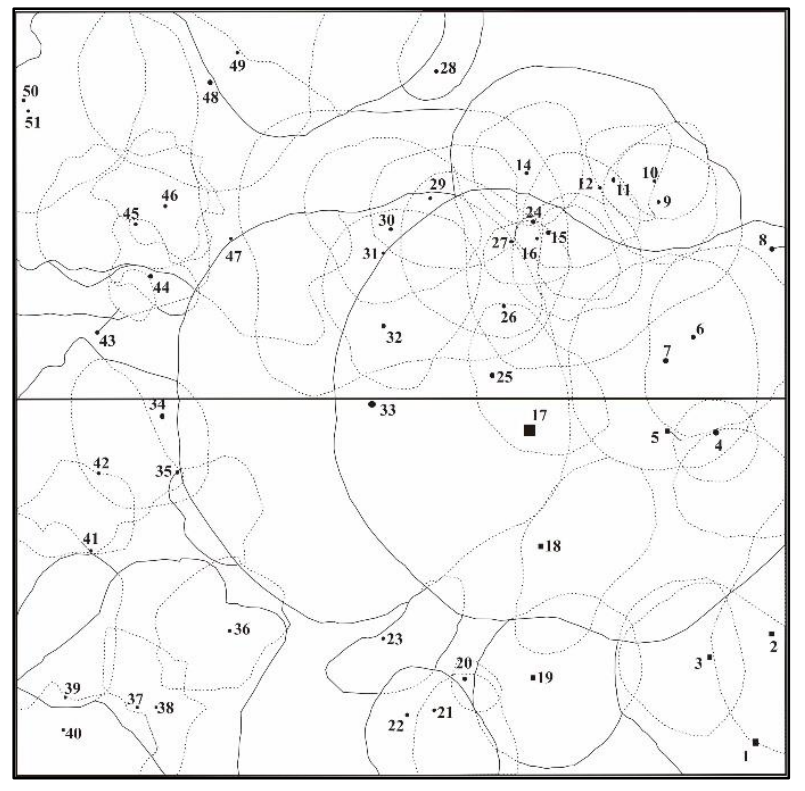

Gambar 6. Proyeksi tajuk pada ketinggian $550 \mathrm{~m}$ dpl (angka menunjukkan nomor pohon)

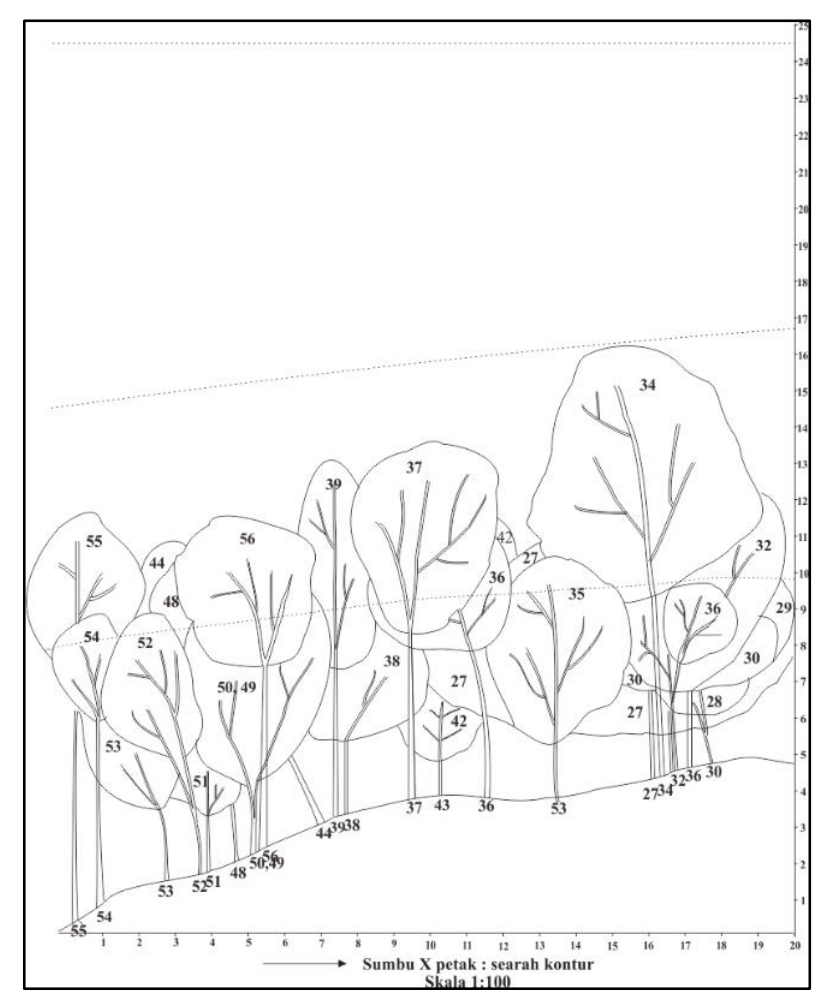

Gambar 7. Diagram profil pohon pada ketinggian $650 \mathrm{~m} \mathrm{dpl}$ (angka menunjukkan nomor pohon)

Pada lokasi ketinggian 650 dan $750 \mathrm{~m}$ dpl nampak bahwa tegakan pohon hanya terdiri atas dua lapisan tajuk hutan yaitu lapisan tajuk paling atas 8-17 $\mathrm{m}$ dan lapisan kedua antara 1-8 m. Lapisan paling atas terdiri oleh jenis Dyctyoneura acuminata, Arthrophyllum diversifolium, Litsea mappacea, Buchanania arborescens, Dillenia serrata, dan Persea rimosa. Lapisan kedua di isi oleh jenis Horsfieldia lancifolia, Rhadermachera pinnata, Mallotus mollissimus, Lithocarpus celebicus, Syzygium rostratum, 
Phyllanthus emblica, Calophyllum sp., Euphorianthus euneurus, dan Psydrax dicoccos. Struktur lapisan dan tutupan tajuk vegetasi hutan pada ketinggian 650 diperlihatkan pada Gambar 7 dan 8,sedangkan struktur lapisan dan tututpan tajuk hutan pada ketinggian $750 \mathrm{~m}$ dpl diperlihatkan pada Gambar 9 dan 10.

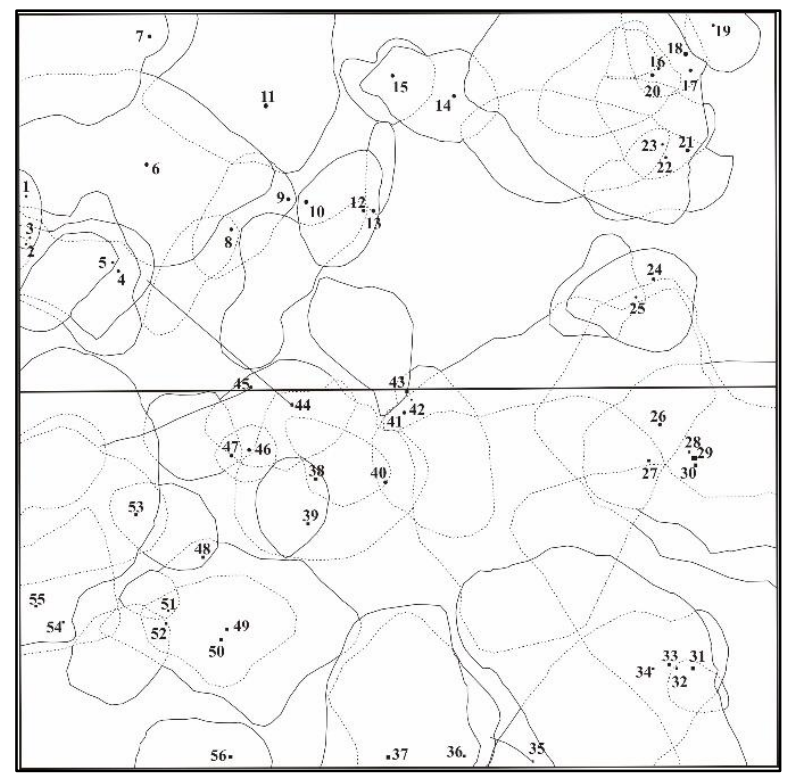

Gambar 8. Proyeksi tajuk pada ketinggian $650 \mathrm{~m}$ dpl (angka menunjukkan nomor pohon).

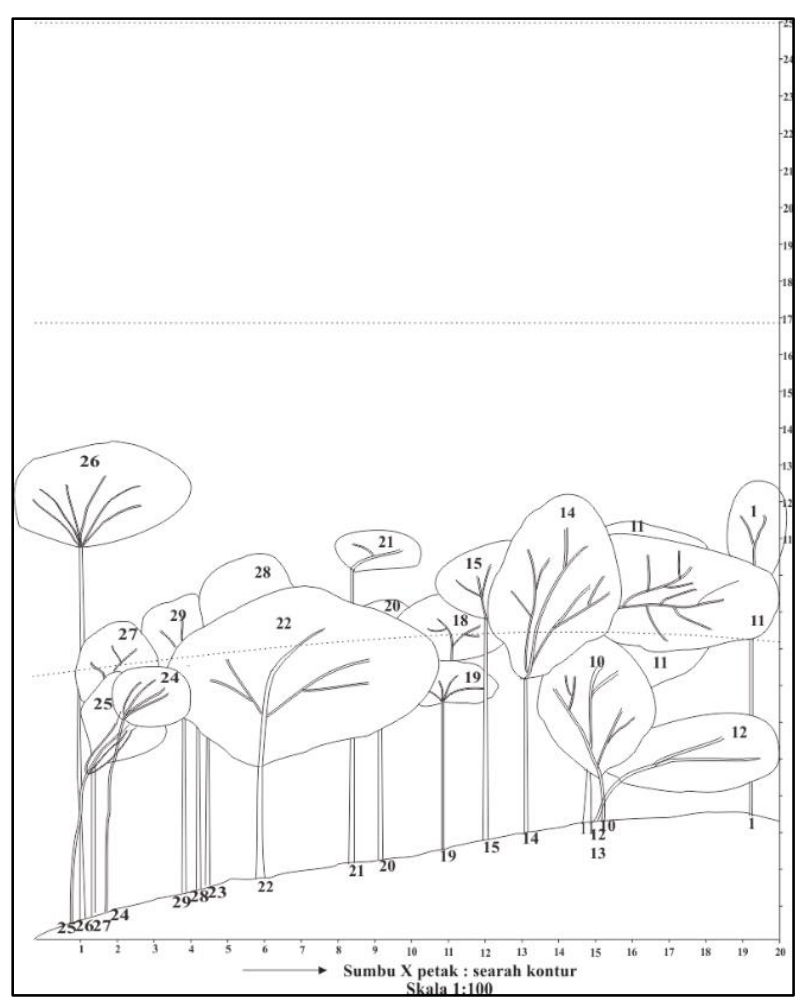

Gambar 9. Diagram profil pohon pada ketinggian $750 \mathrm{~m} \mathrm{dpl}$ (angka menunjukan nomor pohon)

Berdasarkan Gambar 9 dan 10, nampak bahwa tutupan tajuk hutan pada ketinggian 650 dan $750 \mathrm{~m}$ dpl mencapai $75-80 \%$. Dari gambar tersebut terlihat bahwa banyak tajuk yang tumpang tindih. Lapisan tajuk yang tumpang tindih disebabkan oleh tinggi pohon yang berbeda. selain itu, juga disebabkan karena pohon-pohon tumbuh pada lereng, sehingga pohon yang memiliki tinggi yang sama namun tumbuh pada lereng menyebabkan sebagian tajuk berdempetan.

Beradasarkan hasil perhitungan kerapatan individu pada Lampiran 2, 3 dan 4, nampak bahwakerapatan individu seluruh jenis pada setiap lokasi ketinggian cenderung mengalami penurunan berdasarkan kelas tinggi pohon atau kelas lapisan tajuk. Kerapatan individu berdasarkan kelas tumbuhan pada berbagai ketinggian diperlihatkan pada Gambar 11.

\section{Pembahasan}

Berdasarkan hasil penelitian pada hutan rendah di kompleks Gunung Bulusaraung diketahui bahwa pada komposisi dan sebaran jenis ditemukan 95 jenis tumbuhan dari berbagai tingkat pertumbuhan. Jenis-jenis yang mendominasi pada suatu tingkat pertumbuhan tidak selalu mendominasi pada tingkat pertumbuhan berikutnya, bahkan terdapat beberapa jenis tumbuhan yang hanya ditemukan pada tingkat pertumbuhan tertentu. Dendang dan Handayani (2015), menyatakan bahwa tidak semua jenis vegetasi selalu ditemukan pada setiap tingkat pertumbuhan. Hal ini diduga karena hutan dataran rendah pada kompleks Gunung Bulusarung sudah tidak alami disebabkan adanya gangguan hutan berupa penebangan pohon dan tiang yang dilakukan masyarakat sekitar hutan karena lokasi hutan lebih mudah diakses oleh masyarakat sehingga berpengaruh terhadap proses regenerasi, rusaknya ekosistem hutan, dan terjadinya penurunan jenis di kawasan tersebut (Gunawan et al., 2011).

Komposisi jenis yang dinyatakan melalui jumlah jenis dan individu per petak ketinggian di sepanjang jalur pengamatan mengalami perubahan searah dengan ketinggian. Jumlah jenis yang dijumpai pada setiap tingkat pertumbuhan menunjukkan perbedaan pada masingmasing ketinggian. Namun, secara umum, jumlah jenis tumbuhan yang ditemukan cenderung meningkat seiring dengan meningkatnya ketinggian. Kerapatan individu di berbagai ketinggian tempat pada tingkatan semai menurun seiring dengan meningkatnya tingkat pertumbuhan yang merupakan karakteristik tegakan hutan alam tidak seumur (Hilwan, 2012). Namun pada tingkatan pancang, tiang dan pohon kerapatan individu di berbagai ketinggian meningkat seiring dengan meningkatnya tingkat pertumbuhan.

Pada lokasi penelitian, ada beberapa jenis-jenis yang mendominasi pada ketiga ketinggian di tiap tingkatan pertumbuhan. Adapun jenis yang mendominasi seperti Arthrophyllum diversifolium mendominasi pada ketinggian tertentu di tiap tingkatan pertumbuhan.Palaquium obovatum mendominasi di tingkatan pohon pada ketinggian $550 \mathrm{~m}$ dpl dan pada ketinggian $750 \mathrm{~m}$ dpl di didominasi oleh Persea rimosa. Sedangkan pada tingkatan tiang ketinggian $550 \mathrm{~m}$ dpl adalah Cryptocarya 
laevigata. Dyctyoneura acuminata mendominasi pada tingkatan pancang di ketinggian 550 dan $650 \mathrm{~m}$ dpl dan pada ketinggian $750 \mathrm{~m}$ dpl didominasi oleh Cryptocarya ferrea. Dan ditingkatan semai di dominasi oleh Psychotria leptothyrsa pada ketinggian $550 \mathrm{~m} \mathrm{dpl}$, Persea rimosa pada ketinggian $650 \mathrm{mdpl}$, dan ketinggian $750 \mathrm{mdpl}$ ialah Cryptocarya ferrea.

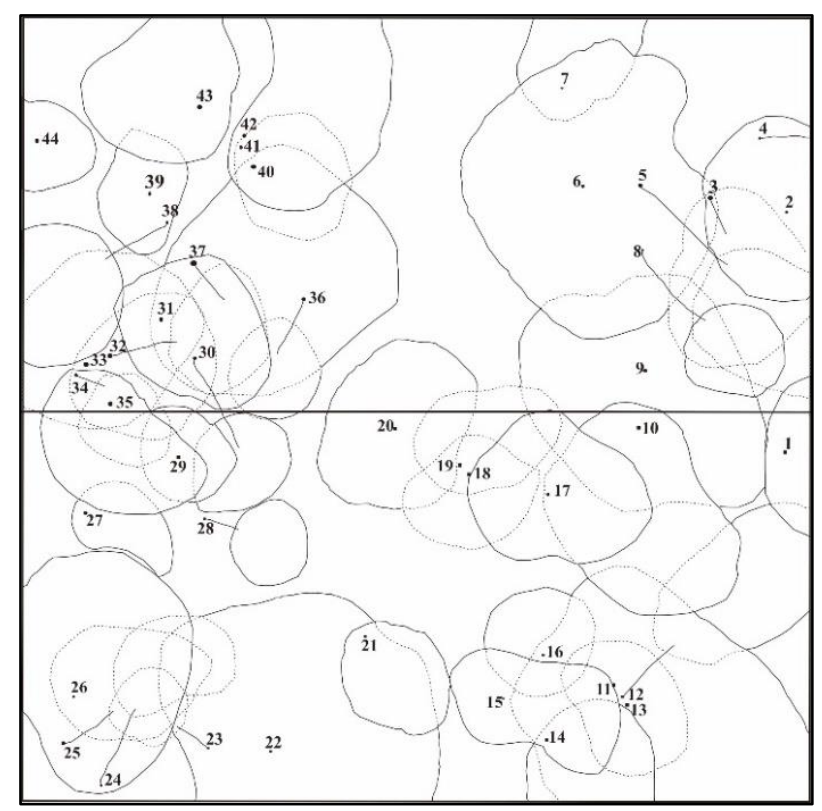

Gambar 10. Proyeksi tajuk pada ketinggian $750 \mathrm{~m}$ dpl (angka menunjukkan nomor pohon)

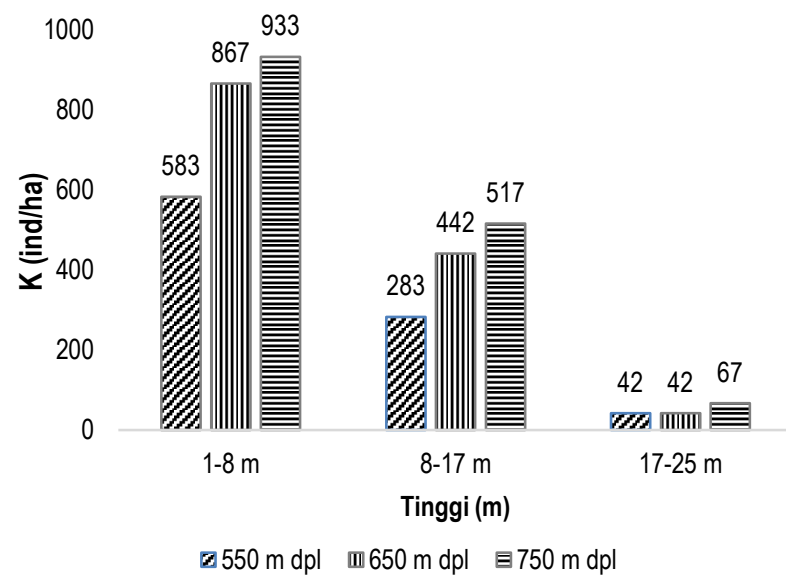

Gambar 12. Kerapatan individu berdasarkan tinggi pohon pada berbagai ketinggian

Tingginya nilai INP suatu jenis disebabkan oleh kerapatan yang besar dan frekuensi yang merata pada seluruh areal. Pada tingkat tiang dan pohon, besarnya diameter batang juga sangat berpengaruh terhadap besarnya nilai indeks penting. Kusmana dan Susanti (2015), menjelaskan bahwa dominannya suatu jenis tumbuhan disebabkan oleh kemampuannya yang lebih baik dalam memanfaatkan sumberdaya yang ada dibandingkan dengan jenis-jenis yang lain.
Indeks keanekaragaman digunakan untuk melihat tingkat keanekaragaman jenis tumbuhan pada suatu komunitas hutan. Berdasarkan data yang disajikan dalam Gambar 6, diketahui bahwa indeks keanekaragaman jenis yang diperoleh tergolong sedang $\left(1<\mathrm{H}^{\prime}<3\right)$ dan tinggi $\left(\mathrm{H}^{\prime}\right.$ $>3$ ). Semakin tinggi keanekaragaman jenis, maka komunitas tersebut akan semakin stabil dan memiliki kemampuan lebih tinggi dalam menghadapi gangguan hutan (Irwan 2009). Nilai indeks keanekaragaman sangat dipengaruhi oleh dua hal yaitu kelimpahan jenis dan kemerataan jenisnya (Mulyasana, 2008). Jika jenis yang ditemukan semakin banyak dan jumlah individupada masing-masing jenisnya merata, nilai indeks keanekaragaman yang diperoleh akan semakin tinggi.

Selanjutnya, indeks kekayaan jenis digunakan untuk mengetahui kekayaan jenis dalam suatu komunitas. Berdasarkan Gambar 6., diketahui bahwa nilai indeks kekayaan tergolong rendah $(R<3.5)$ sampai sedang $(3.5$ $<R<5.0$ ). Nilai indeks kekayaan jenis berbanding lurus dengan jumlah jenis dan individu tumbuhan pada suatu komunitas. Semakin banyak jumlah jenis tumbuhan yang ditemukan, nilai indeks kekayaannya akan semakin besar (Fathia, 2017). Sedangkan pada indeks kemerataan jenis yang diperoleh cenderung mendekati 1. Hal ini menunjukkan bahwa hampir seluruh jenis pada setiap tingkat pertumbuhan di berbagai ketinggian memiliki jumlah individu yang merata. Fathia (2017), menyatakan bahwa penambahan jenis pada suatu komunitas, terutama jenis yang memiliki nilai individu yang rendah dapat berpengaruh signifikan terhadap nilai indeks kemerataan jenis.

Indeks kesamaan komunitas menunjukkan tingkat kesamaan komposisi jenis dari beberapa komunitas yang dibandingkan. Berdasarkan hasil penelitian, diketahui bahwa komposisi jenis pada setiap tingkat pertumbuhan di berbagai ketinggian yang dibandingkan memiliki nilai indeks kesamaan komunitas berkisar antara 49,1 - 62 \%, sehingga komposisi jenis penyusun komunitas cenderung berbeda sampai mirip. Perbedaan komposisi jenis pada suatu komunitas disebabkan oleh kondisi lingkungan yang berbeda (suhu, kelembaban, topografi, dan tanah) dan adanya gangguan hutan (Fathia, 2017).

Struktur tegakan vertikal dapat dilihat dari tinggi pohon. Pembagian kelas tinggi dilakukan dengan mengikuti strata pohon berdasarkan hasil penggambaran dilapangan yaitu lapisan pertama dengan tinggi pohon 17$25 \mathrm{~m}$, lapisan kedua dengan tinggi pohon 8-17 m, dan lapisan ketiga dengan tinggi pohon 1-8 m. Berdasarkan Gambar 14, pohon pada kelas tinggi 1-8 m memiliki kerapatan tertinggi pada berbagai ketinggian. Kerapatan pohon semakin menurun seiring dengan meningkatnya kelas tinggi pohon. Fathia (2017), menyatakan bahwa dengan bertambahnya ketinggian tempat, tinggi pohon akan semakin menurun dan stratifikasi tajuk yang terbentuk akan semakin sederhana. Stratifikasi tajuk ini terjadi karena dua hal penting yang dialami olehtumbuhan dalam persekutuan hidupnya dengan tumbuhan lainnya 
yaitu adanya persaingan antar tumbuhan dan akibat sifat toleransi spesies pohon terhadap intensitas radiasi matahari (Indriyanto 2012).

\section{KESIMPULAN}

Jenis-jenis tumbuhan penyusun hutan dataran rendah di Kompleks Gunung Bulusaraung yang dijumpai pada seluruh tingkatan pertumbuhan adalah 95 jenis. Komposisi jenis di hutan dataran rendah Gunung Bulusaraung didominasi oleh jenis- jenis seperti Palaquium obovatum, Persea rimosa, Arthrophyllum diversifolium, Cryptocarya laevigata, dan Engelhardia serrata. Beberapa jenis yang berbeda dari tiap ketinggian diantaranya Psychotria leptothyrsa, Antidesma bunius, Maesa ramentacea, Ficus amplas, Baccaurea javanica, Symplocos maliliensi, Callicarpa pentandra, dan Saurauia tristyla. Struktur lapisan tajuk hutan terdiri dari dua sampai dengan tiga lapisan tajuk pada setiap ketinggian tempat dengan tutupan tajuk hutan pada tiap ketinggian mencapai $75-90 \%$.

\section{DAFTAR PUSTAKA}

Anwar, J., Damanik S.J., Hisyam N., \& Whitten A.J. (1992). Ekologi Ekosistem Sumatera. Yogyakarta: Gadjah Mada University Press.

Ashton, P.S. (1982). Dipterocarpaceae. In: Van Steenis, C.G.G.J (ed.) Flora Malesiana (9): 237-552.

Dendang, B., \& Handayani W. (2015). Struktur dan komposisi tegakan hutan di Taman Nasional Gunung Gede Pangrango, Jawa Barat. Pros Sem Nas Masy Biodivindon. 1(4).
Fathia, A.A. (2017). Komposisi Jenis dan Struktur Tegakan serta Kualitas Tanah di Hutan Gunung Galunggung Tasikmalaya. Bogor: Institut Pertanian Bogor.

Gunawan, W., Basuni S., Indrawan A., Prasetyo L.B., \& Soedjito H. (2011). Analisis komposisi dan struktur vegetasi terhadap upaya restorasi kawasan hutan Taman Nasional Gunung Gede Pangrango. JPSL. I1(2): 93-105.

Hilwan, I. (2012). Komposisi jenis dan struktur tegakan pada areal bekas tebangan di PT Salaki Summa Sejahtera, Provinsi Sumatera Barat. Jurnal Silvikultur Tropika. 03(03): 155-16.

Indriyanto. (2012). Ekologi Hutan. Jakarta: Bumi Aksara.

Irwan, Z.D. (2009). Prinsip-Prinsip Ekolgi dan Organisasi Ekosistem Komunitas dan Lingkungan. Jakarta: Penerbit Bumi Aksara.

Kusmana, C., \& Susanti S. (2015). Komposisi dan struktur tegakan hutan alam di Hutan Pendidikan Gunung Walat, Sukabumi. Jurnal Silvikultur Tropika. 5(3): 210-217.

Mongabay. (2012). Hutan Dataran Rendah. Diperoleh dari http://www.mongabay.co.id/hutan-dataran-rendah, pada 11 Oktober 2017.

Mulyasana, D. (2008). Kajian keanekaragaman jenis pohon pada berbagai ketinggian tempat di Taman Nasional Gunung Ciremai Propinsi Jawa Barat. Bogor (ID): Institut Pertanian Bogor.

Pamulardi, B. (1999). Hukum Kehutanan dan Pembangunan Bidang Kehutanan. Jakarta: PT Raja Grafindo Persada.

Purwaningsih. (2004). Biodiversitas. Sebaran Ekologi Jenis-jenis Dipterocarpaceae di Indonesia, 5 (2), 89-95.

Soerianegara, I., \& Indrawan A. (2016). Ekologi Hutan Indonesia. Departemen Manajemen Hutan Fakultas Kehutanan. Bogor: Institut Pertanian Bogor.

Undang-Undang Republik Indonesia Nomor 18 Tahun 2013 tentang Pencegahan dan Pemberantasan Perusakan Hutan. 